\title{
Type 2 (non-insulin-dependent) diabetes mellitus, migration and westernisation: The Tokelau Island Migrant study
}

\author{
T. Østbye ${ }^{1}$, T.J.Welby ${ }^{2}$, I. A.M. Prior ${ }^{2}$, C.E.Salmond ${ }^{2}$ and Y.M.Stokes ${ }^{3}$ \\ ${ }^{1}$ Department of Epidemiology and Biostatistics, University of Western Ontario, London, Ontario, Canada, ${ }^{2}$ Department of Community \\ Health, Wellington School of Medicine, and ${ }^{3}$ Department of Laboratory Services, Wellington Hospital, Wellington, New Zealand
}

\begin{abstract}
Summary. The migration of Tokelauans from a traditional atoll in the Pacific to urban New Zealand is associated with an increased prevalence and incidence of Type 2 (non-insulindependent) diabetes mellitus over the period 1968-1982. During the same period, a lesser but definite increase is seen among non-migrants in Tokelau. The age standardised prevalence rates rose from 7.5 and 11.7 to 10.8 and 19.9 per 100 respectively in the male and female migrants compared with an increase from 3.0 and 8.7 to 7.0 and 14.3 per 100 in the nonmigrant males and females respectively. The incidence of diabetes is shown to be consistently higher in the migrants compared to the non-migrants giving relative risks of 1.5 in males and 1.9 in females. The factors most likely contributing to this difference, are changes to a higher calorie, high protein diet, higher alcohol consumption, a greater weight gain and
\end{abstract}

altered levels of physical activity in the migrants. A number of populations in the Pacific have been shown to have a low rate of diabetes in their traditional setting, but may have a genetic predisposition for diabetes which responds to factors in the urban industrialised environment and life-style. The social and economic changes taking place in Tokelau are also clearly increasing the risk of diabetes. To reverse these trends and prevent the development of complications of Type 2 diabetes, it will be important to institute preventive programmes and to follow up the population in both environments for long-term outcomes, including mortality.

Key words: Type 2 (non-insulin-dependent) diabetes mellitus, occurrence, migrants, acculturation, longitudinal studies.
The high prevalence rates of Type 2 (non-insulin-dependent) diabetes, gout, hypertension and coronary heart disease in some groups of Polynesians has initiated a series of epidemiological studies in the Pacific [1-10]. These studies suggest that Polynesians, and, to a varying degree, Melanesians and Micronesians [11, 12], have a genetic predisposition to a disease complex of obesity, hypertension, coronary artery disease, gout and diabetes. These diseases may be precipitated by moving from a traditional to a Western life-style and environment.

Tokelau consists of three small isolated atolls $3200 \mathrm{~km}$ north of New Zealand. Since the mid 1960's Tokelau has experienced a major migration to New Zealand. In 19822800 of all Tokelauans in the combined environments (4360) were living in New Zealand.

The Tokelau Island Migrant Study, established in 1967, provided an opportunity to examine the effect of migration and urbanisation on the occurrence of diabetes mellitus in a genetically homogeneous group $[13,14]$.
Life on Tokelau is traditional. The subsistence economy is dependent on fishing and copra. Migration to New Zealand involves environmental, dietary and sociocultural changes. This report describes the changing occurrence of diabetes as well as weight changes in Tokelau and in New Zealand. It is based on repeated surveys carried out between 1968 and 1982.

\section{Subjects, materials and methods}

The general research plan and methodology of the Tokelau Island Migrant Study has been described previously [13-17].

In Tokelau, the baseline population for this study of Type 2 diabetes comprised 448 adults aged 35 to 74 years seen in either 1968 on the atoll of Fakaofo or in 1971 on the atolls of Atafu or Nukunonu. In these two surveys shorter medical examinations which did not include diagnosis of Type 2 diabetes or medical histories were conducted on the remaining atoll(s) for logistic reasons. A further 21 adults were seen, but were excluded from the Tokelau baseline: 3 people were given shorter examinations in 1968 and then migrated to New Zealand or elsewhere before 1971. Five people were either missed or received a shorter examination in 1971; and 13 women were pregnant. Re-examinations in Tokelau took place in 1976 and 1982; 
Table 1. Prevalence of Type 2 (non-insulin-dependent) diabetes mellitus by sex and migrant status at the end of the study (Round III)

\begin{tabular}{|c|c|c|c|c|c|c|c|c|}
\hline \multirow{3}{*}{$\begin{array}{l}\text { Age } \\
\text { groups }\end{array}$} & \multicolumn{4}{|c|}{ Men } & \multicolumn{4}{|c|}{ Women } \\
\hline & \multicolumn{2}{|c|}{ Migrant } & \multicolumn{2}{|c|}{ Non-migrant } & \multicolumn{2}{|c|}{ Migrant } & \multicolumn{2}{|c|}{ Non-migran } \\
\hline & $n$ & $\begin{array}{l}\text { number } \\
\text { examined }\end{array}$ & $n$ & $\begin{array}{l}\text { number } \\
\text { examined }\end{array}$ & $n$ & $\begin{array}{l}\text { number } \\
\text { examined }\end{array}$ & $n$ & $\begin{array}{l}\text { number } \\
\text { examined }\end{array}$ \\
\hline 35 to 44 & 10 & 128 & 1 & 39 & 11 & 114 & 4 & 63 \\
\hline 45 to 54 & 15 & 81 & 6 & 46 & 16 & 69 & 7 & 62 \\
\hline 55 to 64 & 4 & 51 & 3 & 44 & 7 & 34 & 11 & 41 \\
\hline 65 to 74 & 1 & 16 & 2 & 29 & & 18 & 6 & 22 \\
\hline Total & 30 & 276 & 12 & 158 & 42 & 235 & 28 & 188 \\
\hline
\end{tabular}

369 and 346 people were seen respectively. The overall adult non-participation rate was $4 \%$.

A register of Tokelauans in New Zealand was established and maintained throughout the study. Examinations of all Tokelauans in New Zealand aged 35-74 years were carried out in 1972-1974, 1975-1977 and 1980-1981, and included 362, 399 and 511 adults respectively. The overall adult non-participation rate was $2.8 \%$. The baseline surveys in Tokelau and the initial survey in New Zealand are referred to as round $\mathrm{I}$; the surveys at the middle and the end of the period are referred to as round II and round III respectively. After round I, 464 subjects entered the study, mostly by attaining 35 years of age.

Type 1 (insulin-dependent) diabetes mellitus is virtually unknown in this population, and all cases have been defined as having Type 2 diabetes mellitus. Diagnosis of Type 2 diabetes was based on plasma glucose level and/or a clinical history of Type 2 diabetes.

A standard $100 \mathrm{~g}$ oral glucose load was given to the subject after an overnight fast and a blood sample was taken one $h$ later. This followed the method adopted in the Tecumseh studies [18]. Blood samples were separated and stored in the field at $-15^{\circ} \mathrm{C}$ and transported to the Wellington Hospital Epidemiology Unit Laboratory for analysis. Plasma glucose level was measured using the Beckman Glucose Analyser [19]. Internal quality control was maintained by using commercially prepared stocks of Monitrol I and II.

The diagnosis of Type 2 diabetes was made on the basis of a one $h$ plasma glucose level of $13.9 \mathrm{mmol} / 1(250 \mathrm{mg} / 100 \mathrm{ml})$ or more. This level (chosen in 1968) was marginally lower than that based on the extensive Tecumseh data where a plasma glucose of $14.5 \mathrm{mmol} / 1$ at one $h$ represented a statistically abnormal level (mean $+2 \mathrm{SD}$ ) adjusted to age 40 years [18]. Under reported similar plasma levels (mean $+2 \mathrm{SD}$ : $14.7 \mathrm{mmol} / 1$ at one $\mathrm{h}$ and $12.6 \mathrm{mmol} / 1$ at $2 \mathrm{~h}$ post glucose load). Subsequent analysis of the Tokelau 1968/1971 one h plasma glucose levels gave a mean +2 SD level of $14.5 \mathrm{mmol} / 1$ [20]. Persons known to have had a clinical history of Type 2 diabetes and who had a plasma glucose level of less than $13.9 \mathrm{mmol} / 1$ were also included since treatment may have had a modifying effect [5]. Due to time constraints the glucose load in round III was given only to those of 35 to 74 years of age.

Sensitivity and specificity of the one h level of $13.9 \mathrm{mmol} / 1 \mathrm{com}$ pared with the $2 \mathrm{~h}$ level of $10.0 \mathrm{mmol} / \mathrm{l}$ as the standard for Type 2 diabetes was carried out in 42 subjects given a $100 \mathrm{~g}$ glucose load in 1971. Compared to the $2 \mathrm{~h}$ level recommended by the WHO in 1980 [21], the sensitivity of our criterion was $80 \%$ and the specificity was $82 \%$, justification at that time for the level adopted. When the $\mathrm{Na}$ tional Diabetes Group [22] and the WHO Expert Committee produced new criteria, it was decided that it would be wiser not to change the method and diagnostic criteria in the last round in 1980-1982.

Serum uric acid levels were determined by a method modified by Crowley [23]. Blood was collected and stored at $-15^{\circ} \mathrm{C}$ and assayed for total serum cholesterol and triglyceride concentrations as reported previously [24]. Serum insulin samples at one $h$ post glucose load were collected only in round II and were not used in these analyses.

Body weight was measured on a standard beam scale after an overnight fast. To standardise weight for height, a body mass index $\left(\mathrm{BMI}=\right.$ weight in $\left.\mathrm{kg} / 10 \times(\text { height in } \mathrm{m})^{2}\right)$ was calculated. Subscapular and triceps skin-fold thickness were recorded togehter with arm cir- cumference. No direct measurement of physical activity level was available for objective analysis. Systolic and fourth phase diastolic blood pressures were recorded with a random zero sphygmomanometer $[13,17]$.

Cross-sectional data at each round was used to calculate the age standardised prevalence rate of Type 2 diabetes in migrants and nonmigrants, classified on the basis of their place of residence at the time of an examination. Subjects were included in the Type 2 diabetes incidence study if they were examined in two or more rounds and were free of Type 2 diabetes at entry. Person years at risk of developing Type 2 diabetes were aggregated for each individual over the course of the study or until they were excluded either because they became Type 2 diabetic patients or because they migrated back to Tokelau. For individuals who developed Type 2 diabetes between two rounds, the onset of disease was assumed to have occurred at the midpoint between these two rounds. A minority of the cases had been diagnosed by the family doctor or during hospital attendences. Person years at risk of developing Type 2 diabetes were apportioned to the age groups the individual passed through during the study period. Only those aged between 35 and 74 years at any point during the study period were included.

Analyses are reported separately for men and women. Women who were pregnant at the time of their examination have been excluded from the analyses. Tests of linear trend of Type 2 diabetes prevalence over time were performed using the method of Mantel [25]. Reference populations were constructed by pooling total numbers seen (in the prevalence study) or person years at risk (in the incidence study). In the prevalence and incidence calculations, the direct method of age standardisation was used. Relative risk estimates were calculated by the Mantel-Haenszel method [26].

The relationship between an individual's health status at entry to the study and the subsequent development of diabetes was investigated. Those developing Type 2 diabetes were compared to the rest of the population for their mean BMI, weight, height, upper arm circumference, subscapular and triceps skin-fold thicknesses, systolic and fourth phase diastolic blood pressures, serum cholesterol level, serum triglyceride level and serum uric acid level. The difference in age distribution between the two groups was controlled by analysis of covariance. Univariate and forward stepwise multivariate logistic regression analyses [27] were also carried out. Included as candidate predictors of disease status were the independent variables listed above. Predictors were selected or retained in the "best" model if they were statistically significant at the $5 \%$ level after controlling for the effects of other variables already included. Statistical significance was assessed at the nominal 5\% level for the comparisons made. The Statistical Analysis System [28] was used for the statistical analyses.

\section{Results}

\section{Prevalence}

To demonstrate the trends, prevalent Type 2 diabetes cases in round III are reported in Table 1. Type 2 diabetes tended to occur more frequently in women than in men in both environments. There was a trend for a greater frequency of observed Type 2 diabetic patients in the migrant women than in the non-migrant women. This was not significant $(p=0.25)$. The data suggest that the age of onset was lower in the migrants than in the non-migrants. A similar pattern was observed in the earlier rounds and has been reported previously [5].

Over the three examination rounds the age standardised prevalence of Type 2 diabetes was higher in the migrants than in the non-migrants (Table 2). This was significant only in men in round I when the estimated relative risk of Type 2 diabetes was $2.7(p=0.04)$. 
Table 2. Age standardised prevalence of diabetes by sex and migrant status

\begin{tabular}{|c|c|c|c|c|c|}
\hline \multirow[t]{2}{*}{ Round } & \multicolumn{2}{|c|}{$\begin{array}{l}\text { Cases/number } \\
\text { examined }\end{array}$} & \multicolumn{2}{|c|}{$\begin{array}{l}\text { Type } 2 \text { diabetes } \\
\text { prevalence (per } 100 \text { ) }\end{array}$} & \multirow{2}{*}{$\begin{array}{l}\text { Relative risk } \\
\text { for migrants vs } \\
\text { non-migrants } \\
\text { (and } 95 \% \text { confi- } \\
\text { dence limits) [26] }\end{array}$} \\
\hline & Migrant & $\begin{array}{l}\text { Non- } \\
\text { migrant }\end{array}$ & Migrant & $\begin{array}{l}\text { Non- } \\
\text { migrant }\end{array}$ & \\
\hline \multicolumn{6}{|l|}{ Males } \\
\hline I & $16 / 208$ & $6 / 197$ & 7.5 & 3.0 & $2.7(1.08 ; 7.02)$ \\
\hline II & $15 / 223$ & $9 / 157$ & 7.1 & 5.1 & $1.2(0.71 ; 2.20)$ \\
\hline III & $30 / 276$ & $12 / 158$ & 10.8 & 7.0 & $1.3(0.85 ; 2.14)$ \\
\hline \multicolumn{6}{|l|}{ Females } \\
\hline I & $18 / 154$ & $20 / 230$ & 11.7 & 8.7 & $1.4(0.75 ; 2.49)$ \\
\hline II & $30 / 176$ & $25 / 212$ & 18.3 & 11.5 & $1.6(0.98 ; 2.57)$ \\
\hline III & $42 / 235$ & $28 / 188$ & 19.9 & 14.3 & $1.3(0.87 ; 2.03)$ \\
\hline
\end{tabular}

With the exception of migrant men in round II the age standardised prevalence increased over time in all subgroups. A test for linear trend in prevalence over the three rounds showed a significant increase among the non-migrant women (Chi-square $(1)=4.7 ; p=0.03$ ), but not among the other groups.

\section{Incidence}

Table 3 shows that there were a total of 46 new cases of Type 2 diabetes in the migrants and 38 in the nonmigrants between 1968 and 1982. The age standardised incidence rates were higher in migrants than in the non-migrants. The age standardised relative risk of developing Type 2 diabetes was 1.9 in the migrant vs the non-migrant women (Chi-square $(1)=4.6 ; p=0.03$ ).

The subjects who developed Type 2 diabetes during the study were on average older at the point of entry than the subjects who did not develop Type 2 diabetes (Table 4), although this was only 0.91 of a year difference
Table 3. Age standardised incidence rates of Type 2 (non-insulin-dependent) diabetes in migrant and non-migrant Tokelauans between 1968 and 1982

\begin{tabular}{|c|c|c|c|c|}
\hline & \multicolumn{2}{|l|}{ Men } & \multicolumn{2}{|l|}{ Women } \\
\hline & Migrant & $\begin{array}{l}\text { Non- } \\
\text { migrant }\end{array}$ & Migrant & $\begin{array}{l}\text { Non- } \\
\text { migrant }\end{array}$ \\
\hline Cases & 20 & 14 & 26 & 24 \\
\hline Person years at risk & 1576 & 1608 & 1080 & 1758 \\
\hline $\begin{array}{l}\text { Incidence } \\
\text { (new cases per } 10,000 \\
\text { person years at risk) }\end{array}$ & 124.6 & 84.6 & 253.8 & 133.4 \\
\hline $\begin{array}{l}\text { Relative risk [26] } \\
\text { (migrant vs non-migrant, } \\
\text { and } 95 \% \text { confidence } \\
\text { limits) }\end{array}$ & $1.5(0.7$ & ; 3.04) & $1.9(1$ & $1 ; 3.24)$ \\
\hline
\end{tabular}

in the men and 4.14 years in the women. After controlling for age differences at entry, the mean levels of most body mass measures were significantly $(p<0.05)$ higher in both men and women who developed Type 2 diabetes than in those who did not (Table 4).

Serum cholesterol and serum uric acid levels were not significantly different in either sex. Average systolic blood pressure and serum triglycerides were significantly higher in the female incidence cases but not in the males. There was generally more variability about the means for anthropometric measures among the future Type 2 diabetic patients than among those who did not develop Type 2 diabetes.

\section{Body weight and BMI changes 1968-1982}

In the period between the baseline studies (1968-1971) and 1982 the weights and body mass indices (Table 5) have shown a notably greater increase in the migrants than in the non-migrants.

Table 4. Age standardized risk factors at entry for men and women in the Type 2 (non-insulin-dependent) diabetes incidence study

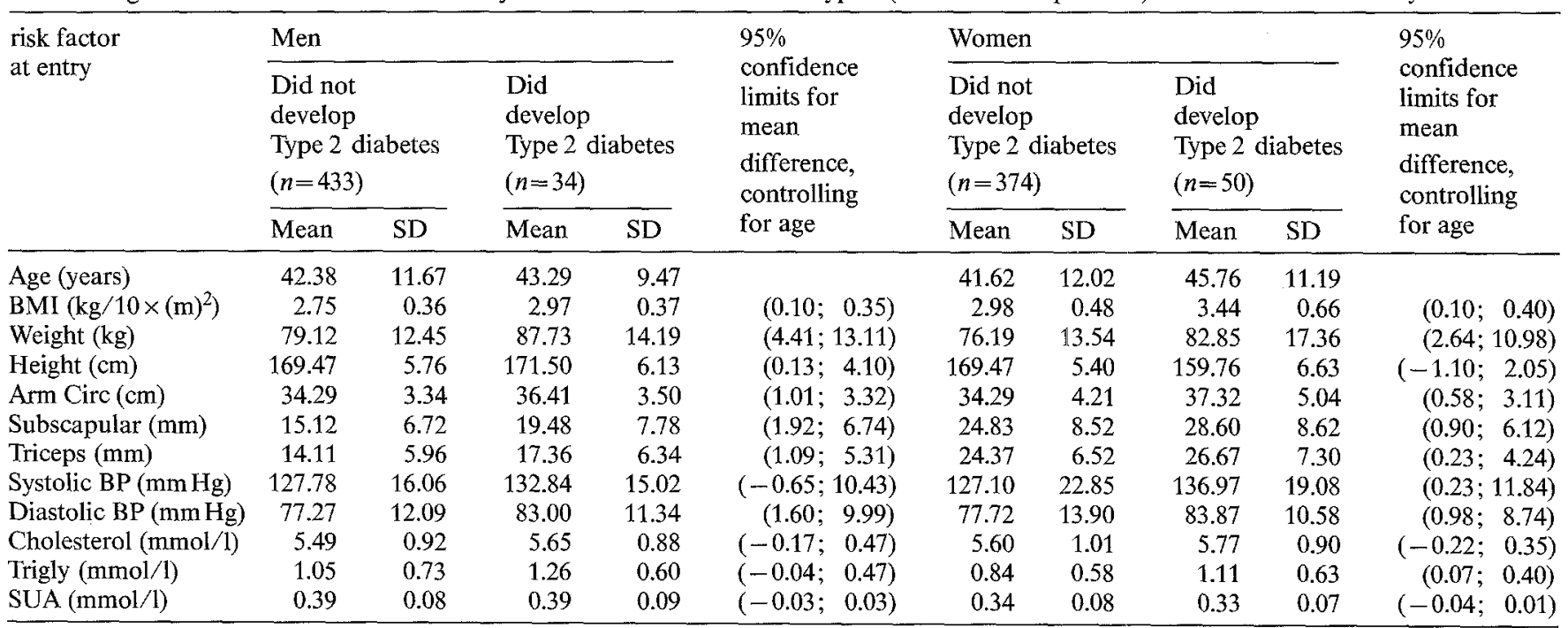

$\mathrm{BMI}=$ Body mass index $;$ Circ $=$ Circumference $;$ trigly $=$ Triglyceride $;$ SUA $=$ Serum uric acid 
Table 5. Changes in body mass index (by sex and migrant status (Weight $\left.(\mathrm{kg}) / 10 \times(\text { height }(\mathrm{m}))^{2}\right)$; Mean values, SD in parentheses)

\begin{tabular}{llllll}
\hline \multirow{2}{*}{ Round } & Men & & \multicolumn{2}{l}{ Women } & \\
\cline { 2 - 3 } \cline { 5 - 6 } & Migrant & Non-migrant & & Migrant & Non-migrant \\
\hline I & $2.41(0.31)$ & $2.48(0.30)$ & & $2.78(0.40)$ & $2.88(0.51)$ \\
III & $2.87(0.42)$ & $2.61(0.38)$ & $3.18(0.52)$ & $3.01(0.52)$ \\
\hline
\end{tabular}

It should be noted that the BMI levels in Table 4 were higher at entry in the incidence cases in both sexes.

\section{Logistic regressions}

Univariate logistic models relating risk factors at entry to the incidence of Type 2 diabetes over the 14 years of the study were constructed. In the univariate analysis, all the confounding variables considered, except for age, height, serum cholesterol, triglycerides and uric acid levels in men and women, and systolic blood pressure in men, were positively associated with the incidence of diabetes (an increase in each risk factor contributed to an increase in risk of Type 2 diabetes). A forward stepwise multivariate model including candidate Type 2 diabetes incidence predictors yielded models of poor predictive power. For the men, subscapular skin-fold thickness was the best significant predictor, and no other variables provided further significant improvements in the prediction of diabetes. For the women, BMI and serum triglyceride levels were the best set of predictors of Type 2 diabetes incidence. The percentages of variance accounted for by each of these regressions were $4 \%$ in the men and $4 \%$ in the women. When age and body mass were included in the above models no other terms in the logistic regressions were significant. The percentages of the total variance accounted for in these models were 2 and $4 \%$ for men and women respectively. Multicollinearity was not a problem in selecting the best predictors.

\section{Discussion}

The extraordinary range of Type 2 diabetes in the Pacific region includes prevalence rates of $1.5 \%$ in rural Melanesians in Fiji [11] and 30\% in the affluent and urbanised Nauruans [29]. The Tokelau baseline study carried out in 1968-1971 gave prevalence rates of $2.3 \%$ in the men and $6.1 \%$ in the women [5] which are comparable with some of the other groups such as Niue [30], Rarotonga [30] and urban Samoa [9].

There are limited data available about Type 2 diabetes rates in Caucasians in New Zealand, indicating prevalence rates of $4 \%$ male and female in Rangiora in 1969 [31]. The screening method varied from that used in the Tokelau Study but it seems clear that the baseline prevalences in Tokelau are higher than in non-
Polynesians in New Zealand. A number of these studies took place in the 1970's before a standard definition of Type 2 diabetes had been developed. Comparisons between studies must therefore be made with caution. The same method and criteria were used in the Tokelau study and the New Zealand Maori study [6] so that the current findings can be compared with the prevalences of $12.0 \%$ in Maori men and $12.5 \%$ in Maori women.

In the Tokelauans, migration and urbanisation has involved a whole series of life-style and diet changes which may have led to the development of higher diabetes rates. Moving from the subsistence economy in Tokelau with traditional values, customs and diet patterns to adapt to urban New Zealand society with a wage economy and the need to learn new skills was the major change that faced the Tokelau migrants in the early 1970's.

It is likely that the increased occurrence of Type 2 diabetes in both non-migrants and migrants is related to the weight changes in both groups. Increased energy intake occurred in both groups [16]. There have been some changes in the diet pattern in Tokelau with more use of "western food", particularly rice, flour and tinned goods and less consumption of traditional foods including coconut and fish. In New Zealand the migrants face an increased availability of carbohydrates in the form of sugar, flour, bread and potatoes, meat, chicken and dairy products.

The amount of sugar consumed in Tokelau has increased dramatically from around $7 \mathrm{~g}$ per person per day in 1968 to about $55 \mathrm{~g}$ in 1980. Simple sugar has often been singled out as responsible for a qualitative effect on the development of Type 2 diabetes, but this is a controversial issue [32]. Over this period the daily carbohydrate intake has increased from $166 \mathrm{~g} \mathrm{(35 \%} \mathrm{of} \mathrm{en-}$ ergy) to $202 \mathrm{~g}(43 \%)$ and the fat intake has declined from $119 \mathrm{~g}(56 \%)$ to $92 \mathrm{~g}(44 \%)[6]$.

The pattern of alcohol use is also changing. In Tokelauans in both environments this represents changing attitudes to its use [33]. The age standardised use in round I and II was $63 \%$ and $73 \%$ for migrant men in New Zealand and $36 \%$ and $62 \%$ for non-migrant men in Tokelau, respectively.

There is an overall weight increase in the migrants soon after coming to New Zealand and this is sustained to a greater extent than it is in Tokelau as people get older. Tokelauans have traditionally had no social constraints against obesity, although this may now be starting to change in younger people as they observe the weight patterns in non-Maori New Zealanders.

The higher prevalence of Type 2 diabetes in women is not found in all societies and may be explained in this study by their greater measure of obesity, by the more sedentary life-style they adopt and possibly other constitutional factors. Higher rates in women are relatively common in the Pacific $[9,29,34]$. The relationship between exercise, diet and obesity is complex and the factors are difficult to separate in observational studies 
[35-37]. In a recent report of the incidence studies of the Pima Indians [36] it was suggested that obesity was only weakly associated with the development of Type 2 diabetes when there was no family history of Type 2 diabetes. This illustrates the probable importance of genetic factors.

In the absence of individual data relating to dietary intake and life-style (including exercise pattern), the comparison of age standardised factors at entry between those who developed Type 2 diabetes and those who did not, provides some insights. The future incidence cases of Type 2 diabetes were already showing higher values for the obesity measurements at time of entry. However, in the forward stepwise multivariate model the candidate variables for Type 2 diabetes incidence prediction yielded models of rather poor predictive power.

During their relatively short time in New Zealand, Tokelauans having come from a much lower risk status in Tokelau, have approached the New Zealand Maori in their risk of Type 2 diabetes [6]. Earlier work described the link between "westernisation" and metabolic maladies of the New Zealand Maori and the serious implications it has for a disease complex including hypertension, coronary artery disease, obesity, diabetes, hyperuricaemia, gout, and, as a complication, renal failure [1, 2]. A longitudinal survey of gout in the Tokelauans has shown a relative risk of gout of 9 in the migrants compared with the non-migrants [38]. These rates are still lower than those found in the Maori study [2], where a high rate of the combined disorders was found. The rates of the combined disorders are low in the Tokelauans but may well increase with time in New Zealand.

Increased prevalence of hypertension and coronary artery disease is a major problem among the New Zealand Maori. These disorders have not yet become a problem with Tokelauans in New Zealand or in Tokelau.

Changes in diet, weight gain and life-style are probably the most important causes contributing to the changes observed in the Tokelau people. As Polynesians they share with the Maoris some similarities in genetic background which could predispose them to Type 2 diabetes, hyperuricaemia and gout. While the New Zealand Maoris have had a long period of transition from their traditional life-style to westernised diet and life-style pattern, it has been a much more abrupt series of changes for the Tokelauans in New Zealand and to a lesser extent in Tokelau. The tempo is likely to accelerate further in the future unless preventive programmes are instituted.

The present study has shown increasing prevalence and incidence of diabetes in the Tokelauan migrants, highlighting the development of a serious health problem. The next step must be to work out ways and means of developing public health eduction programmes that involve the Tokelau community in both Tokelau and in
New Zealand in such a way that their basic knowledge of the disorder is developed and the relationships of obesity to Type 2 diabetes is better understood [21].

Acknowledgernents. The authors acknowledge the support of the Medical Research Council of New Zealand, the Cardiovascular Disease Unit of the World Health Organisation, and the Wellington Hospital Board. The continued co-operation of Tokelau people in Tokelau and in New Zealand is gratefully acknowledged.

\section{References}

1. Prior IAM, Rose BS, Davidson F (1964) Metabolic maladies in New Zealand Maoris. Br Med J 1: 1065-1069

2. Prior IAM, Rose BS, Harvey HPS, Davidson F (1966) Hyperuricaemia, gout and diabetic abnormality in Polynesian people. Lancet I: 333-338

3. Prior IAM, Davidson F (1966) The Epidemiology of diabetes in Polynesians and Europeans in New Zealand and the Pacific. NZ Med J 65: 375-383

4. Sloan CL (1963) Ethnic distribution of diabetes mellitus in Hawaii. JAMA 183: 419-424

5. Stanhope JM, Prior IAM (1980) The Tokelau Island Migrant Study: Prevalence and incidence of diabetes mellitus. NZ Med J 92: 417-421

6. Prior IAM, Brauer GW (1979) Epidemiology of diabetes in the Pacific. In: Ahuja MMS (ed) Epidemiology of diabetes in developing countries. Interprint, New Delhi, pp 63-79

7. Prior IAM, Beaglehole R, Davidson F, Salmond CE (1978) The Relationship of diabetes, blood lipids and uric acid levels in Polynesians. In: Benuet PH, Miller M (eds) Advances in metabolic disorders. Academic Press, New York, pp 241-261

8. Prior IAM (1974) Diabetes in the South Pacific. In: Hillebrand SS (ed) Eighth sugar research symposium. The International Sugar Foundation, Bethesda, pp 4-11

9. Zimmet P, Faaiuso S, Ainuu J, Whitehouse S, Milne B, DeBoer W (1981) The prevalence of diabetes in the rural and urban Polynesian populations of Western Samoa. Diabetes 30:45-51

10. Zimmet P, Canteloube D, Genelle B, LeGonidec G, Couzigou P, Peghini M, Charpin M, Bennett P, Kuberski T, Kleiber N, Taylor R (1982) The prevalence of diabetes mellitus and impaired glucose tolerance in Melanesians and Part-Polynesians in rural New Caledonia and Ouvea (Loyalty Islands). Diabetologia 23:393-398

11. Zimmet $P$, Taylor R, Ram P, King H, Sloman G, Raper LR, Hunt D (1983) Prevalence of diabetes and impaired glucose tolerance in the biracial (Melanesian and Indian) population of Fiji: a rural-urban comparison. Am J Epidemiol 118: 673-688

12. Martin FIR, Wyatt GB, Griew AR, Haurahelia M, Higginbotham L (1980) Diabetes mellitus in urban and rural communities in Papua New Guinea. Diabetologia 18: 369-374

13. Prior IAM, Stanhope JM, Evans JG, Salmond CE (1974) The Tokelau Island Study. Int J Epidemiol 3: 225-332

14. Ward RH, Raspe PD, Ramirez ME, Kirk RL, Prior IAM (1979) Genetic structure and epidemiology: the Tokelau Island Migrant study. In: Eriksson AW, Forsius A, Nevalinna H (eds) Population genetic studies on isolates. Academic Press, London, pp 301-325

15. Prior IAM; Davidson F, Salmond CE, Czochanska Z (1981) Cholesterol, coconuts and diet on Polynesian atolls: a natural experiment: the Pukapuka and Tokelau Island studies. Am J Clin Nutr 34: 1552-1561

16. Harding WR, Russell CE, Davidson F, Prior IAM (1986) Dietary surveys from the Tokelau Island Migrant Study. Ecology of Food and Nutrition 19: 83-97

17. Prior IAM, Hooper A, Huntsman JW, Stanhope JM, Salmond CE (1977) the Tokelau Island Migrant study. In: Harrison GA (ed) Population structure and human variation. Cambridge University Press, Cambridge, Int Biol Prog, pp 165-186 
18. Hayner NS; Kjelsberg MO, Epstein T (1965) Carbohydrate tolerance and diabetes in a total community, Tecumseh, Michigan. 1. Effects of age, sex and test conditions on one-hour glucose tolerance in adults. Diabetes 14: 413-423

19. Beckman glucose analyser operating manual (1969) Beckman Instruments, Fullerton, USA

on Siperstein MD (1974) The glucose tolerance test. A pitfall in the diagnosis of diabetes mellitus. Diabetes 23: 297-323

21. WHO Expert Committee on diabetes mellitus. Second Report (1980) Technical Report Series 646, WHO Geneva

22. National Diabetes Data Group (1979) Classification and diagnosis of diabetes mellitus and other categories of glucose intolerance. Diabetes 28: 1039-1057

23. Crowley LV, Alton FI (1968) Automated analysis of uric acid. Am J Clin P 49: 285-288

24. Stanhope JM, Sampson VM, Prior IAM (1981) the Tokelau Migrant study: serum lipid concentrations in two environments. $J$ Chron Dis 34: 45-55

25. Mantel N (1963) Chi-square tests with one degree of freedom: extensions of the Mantel-Haenszel procedure. J Am Stat Assoc 58: $690-700$

26. Mantel M, Haenszel W (1959) Statistical aspects of the analysis of data from retrospective studies of disease. $\mathbf{J}$ Natl Cancer Inst 22: 719-48

27. SAS Institute, Inc (1982) SAS Supplementary user's guide. SAS Institute, Raleigh, USA

28. SAS Institute, Inc. SAS user's guide (1981) SAS Institute, Raleigh, USA

29. King H, Zimmet P, Raper LR, Balkau B (1984) Risk factors for diabetes in three Pacific populations. Am J Epidemiol 119: 396-409

30. King H, Taylor R; Koteka G, Nemaia H, Zimmet P, Bennett PH, Raper LR (1986) Glucose tolerance in Polynesia-Population based surveys in Rarotonga and Niue. Med J Aust 145: 505-510
31. Beaven DW, Arcus AG, Bell JP, Smith JR (1974) Epidemiology of diabets mellitus. NZ Med J 80: 291-299

32. West KM (1978) Epidemiology of diabetes and its vascular complications. Elsevier, New York

33. Stanhope JM, Prior IAM (1979) The Tokelau Island Migrants Study: Alcohol consumption in the two environments. NZ Med J 90: 419-421

34. Zimmet $P$, Seluka A, Collins J, Currie P, Wicking J, DeBoer W (1977) Diabetes mellitus in an urbanized isolated Polynesian population. Diabetes 26: 1101-1108

35. Zimmet P (1982) Type 2 (non-insulin-dependent) diabetes - an epidemiological overview. Diabetologia 22: 399-411

36. Knowler WC, Pettitt DJ, Savage PJ, Bennett PH (1981) Diabetes incidence in Pima Indians: contributions of obesity and parental diabetes. Am J Epidemiol 113: 144-156

37. Balkau B, King H, Zimmet P, Raper R (1985) Factors associated with the development of diabetes in the Micronesian population of Nauru. Am J Epidemiol 122: 594-605

38. Prior IAM, Welby TJ, Østbye T, Salmond CE, Stokes YM (1987) Migration and gout: The Tokelau Migrant study. Br Med J 295: 457-61

Received: 30 January 1989

and in revised form: 24 April 1989

Dr. T.Østbye

Department of Epidemiology and Biostatistics

Kresge Building

University of Western Ontario

London, ON N6A 5C1

Canada 